\title{
Human Elements and their Influence on Student Satisfaction at Selected Public Universities in Kenya
}

\author{
Thomas Waweru Gakobo \\ School of Business, Laikipia University, PO Box 1100-20300 Nyahururu, Kenya \\ Prof. Isaac Ochieng \\ School of Business, Laikipia University, PO Box 1100-20300 Nyahururu, Kenya \\ Dr. Paul Muoki Nzioki \\ School of Business, Laikipia University, PO Box 1100-20300 Nyahururu, Kenya
}

\begin{abstract}
The number of higher education seekers has been increasing globally and in particular this sector has been the fastest growing industry in Kenya. The demand for higher education has been amplified by the liberalization of education in the country which has seen heavy investment and expansion in higher education. However the increased student enrolment in these institutions has unfortunately been met with reduced government funding for Public Universities resulting to serious challenges in service quality delivery and student satisfaction. These challenges have in many occasions led to students' unrests resulting to disruption of studies and university operations. As service institutions, public universities depend heavily on both teaching and non-teaching staff to deliver their services. The funding crisis in the higher education has left public universities unable to only to attract and retain qualified staff but also to recruit adequate permanent staff. This has forced most of these institutions to rely on casuals and part time teaching staff which causes a serious threat to quality in service delivery and student satisfaction. The study aimed at examining how and to what extent human elements of service influences student satisfaction. The study employed a descriptive research design. Stratified random sampling procedure was used to pick a sample of 1976participants from a target population of 270,120 students from the selected five public universities. The study used a questionnaire to collect data from the sampled students and a pick and drop process of administering the questionnaires was used. Regression analysis and ANOVA were used to analyze the data and to test the research hypotheses. The study findings indicated that, human elements positively and significantly influenced satisfaction of student at public universities in Kenya $(F=2575.326, p<0.05)$. The study concluded that employee in public univerities are critical in the satisfaction of students with the services offered by the universities. This study recommended that management of public universities invest well in their human capital to enable the deliver the quality of services necessary for student satisfaction.
\end{abstract}

Keywords: Human Elements, Student Satisfaction, Public Universities

DOI: $10.7176 / \mathrm{EJBM} / 11-20-05$

Publication date:July $31^{\text {st }} 2019$

\section{Introduction}

In the higher education sector, student satisfaction has been seen as a temporary attitude which is formed when a student undergoes through an educational experience. Thus students' satisfaction is an essential management concern for any learning institution such as the Public Universities in Kenya if such institutions have to achieve their objectives and ensure their survival in a competitive market environment. The two definitions present no difference between the customer and the student in higher education setting. Majority of modern service marketing theory and research on services advocates for the treatment of the customer as an active participant in the delivery of service and responsible for the outcome and therefore is also responsible for his/her satisfaction (Mark, 2013; Zeithaml, Bitner, \& Gremler, 2006). Moreover, according to Marcel and Harris (2000), looking at a student as a customer or not will in most cases depend on how one describes a customer. If Public Universities take students as consumers of their education services who can add value through their active participation in the process of education service delivery, then students ought to be seen as the primary customers for Public Universities, a view that is adopted by this study. Thus given this view that the primary customers of education services are the student, the term customer and student were understood to mean the same for this study and is used in alternate. The customer will be satisfied with received services or not, depending on whether the expectations of that customer are finally met or not (Yllmaz, 2009). This means that, and wants of a customer, if that service is packaged and delivered in a way that service quality will fulfill the needs meets the expectations of that customer (Alniack \& Özbek, 2009). For instance, if one of the most important expectations of a student from his or her university is timely feedback on exam result, that student will be satisfied with the university services when this expectation is fulfilled. Otherwise, the opposite will lead to the student being dissatisfied. For service quality to be fulfilling, it must satisfy the customer expectation, and for Ciftci (2006), when quality is below expectation, that quality is 
assumed not to exist. According to Chen, Pei-Yu and Hitt, (2002), each quality factor has a diverse amount of effect on overall service quality and finally on customer satisfaction. Satisfaction or dissatisfaction of a customer is also seen as a "cognitive or reaction" that arises from an encounter of a single or prolonged set of service (Rust \& Oliver, 1994). It is a post evaluation that compares the perceived quality with expected quality.

The demand for higher education has been increasing globally but in Kenya it has been has risen rapidly over the past few years (Abagi, Nzomo, \& Otieno, 2010). The demand has been amplified by the liberalization of education in Kenya which has seen heavy investment and expansion in higher education. The emergence of many private universities which were established to cater for the students not absorbed by the Public Universities is a clear evidence of this growth (Abagi et al., 2010). In addition a number of university colleges have been upgraded to full-fledged universities, thus increasing the total number of Public Universities in Kenya. According to Kiboiy (2013), the expansions universities in Kenya have been very rapid whereby middle level colleges have been converted to university constituent colleges. The number of Public Universities in particular has continued to increase where to date we have 31 fully chartered Public Universities and five Public University Constituent Colleges in Kenya (CUE, 2017)

The above reported growth leading to increased student enrolment in these institutions has unfortunately been met with reduced government funding for Public Universities (GoK, 1988; Boit, 1988). As a result of this government reduced funding, universities have been forced to seek alternative means to generate extra income to finance their recurrent expenditure (Owino, 2013). The proliferation of regional campuses and increased selfsponsored programmes in Public Universities to enhance their resource bases is an attestation to this phenomenon. The rapid expansion of Public Universities' has raised critical questions on quality of services offered in these institutions. As noted by (Ngware, Onsomu, \& Manda, 2005), the current situation in public universities in Kenya does not support or lead to quality education services which results to customer dissatisfaction. Quality service in higher education must be prioritized if these institutions of higher learning will continue to attract and retain students for sustainability. Given the relationship between service quality on student satisfaction and borrowing the thought of Tierney (1998), it therefore means that, universities in Kenya must offer service that meet student expectation in order for those students to desire for more and better quality education and recommend the universities to their friends. Public universities have been pushed beyond their capacities sometimes making them unmanageable. As a result, these institutions lack adequate permanent teaching staff, which forces them to depend largely on part time lecturers causing a serious threat to quality education services (Sifuna, 1988). This is due to the fact that part time lecturers hold their loyalty to their other place of work or work as freelance with no loyalty to any institution. Furthermore, the part time lecturers usually teach in several universities and as such their time to undertake research is limited which is likely to compromise their quality of teaching. The situation is further complicated when full time lecturers also engage in part time teaching outside their own university. According to Abagi (1999), more than half of the lecturers in the Kenyan public universities teaches in other universities as part time job. The study further noted that due to the low salaries, only $5 \%$ of the teaching staff in these institutions undertakes meaningful work in research while others are engaging mostly in consultancies. This means that, these lecturers are left with no time to attend to students issues and even to adequately prepare for their lectures. Anderson and Fornell (1994) noted that, universities must continuously work on meeting and surpassing students' anticipations. However, Otieno and Levy (2007) observed that, the issue of quality continues to be a serious alarm in Kenyan Public Universities which end up in distraction of academic programmes due to student unrest. The decreasing quality of service in public universities has also attracted the regulating authority, CUE, to recommend the closure of these satellite campuses. Jenkins (1992) argued that, the main reason behind the failure of service quality in many organizations can be blamed on the lack of commitment from the top management. When employees are satisfied with the management support, they replicate the same to the customers they serve. As such according to Bohlander and Kinicki (1988), management commitment usually affects the perception of employees in a way that influences their attitude and the general organizational effectiveness. When employee feel appreciated as a result of management support, the are likely to reciprocate the same by treating the customers well. In support of this view, Bowen and Lawler (1992) argued that, employees will provide poor services to customers whenever they feel their work of service delivery is insulting, demeaning and humiliating. Thus, management of organizations should ensure employees are satisfied with their job in order to develop a commitment for both the employees and the customers (Bombard, 1990). Job satisfaction enhances positive employees' behavior, and strengthens the teamwork in the organization that enables them to offer good service to customers. According to Jenkins (1992), the main reason behind the failure of service quality in many organizations can be blamed on the lack of commitment from the top management. When employees are satisfied with the management support, they replicate the same to the customers they serve. As such according to Bohlander and Kinicki (1988), management commitment usually affects the perception of employees in a way that influences their attitude and the general organizational effectiveness. When employee feel appreciated as a result of management support, the are likely to reciprocate the same by treating the customers well. In support of this view, Bowen and Lawler (1992) argued that, employees will provide poor services to customers whenever they feel their work of service delivery is insulting, 
demeaning and humiliating. Thus, management of organizations should ensure employees are satisfied with their job in order to develop a commitment for both the employees and the customers (Bombard, 1990). Job satisfaction enhances positive employees' behavior, and strengthens the teamwork in the organization that enables them to offer good service to customers.

Abomaleh and Zahari (2014) observed that, public sectors, such as Public Universities must recognize the critical role that the employee play in ensure the overall success of these institutions. The employees in Public Universities carry the image of universities they serve. Consequently these employees determine the perception of students on the kind of service they receive from their institutions. Therefore, top managements of these universities must direct their efforts towards improving the effectiveness of those employees offering services.

\section{Literature Review}

Human element of service has been defined as all aspects of the one delivering the service to the customer which includes but not limited to responsiveness reliability, empathy and assurance (Chebet et al. 2000). According to Chebet et al. (2000), reliability includes performing the promised services in dependable and accurate manner. They noted that performing the right thing in the first instance forms the critical components for customer satisfaction. In addition, responsiveness will be demonstrated when the staff serving students the reception for instance are ready to assist and offer them services promptly and in a more professional way. It also involves performing the needed services in a timely manner, thus, it is critical that those providing the needed services ought to do so on time if they are to achieve service quality. In addition, assurance is exhibited when service providers demonstrate their capacity to demonstrate confidence, competence, credibility, trust, security, and courtesy in their service delivery (Chebet et al., 2000). Finally, empathy is demonstrated when service providers offer services in a caring manner while giving individualized attention to customers, that is, allowing them to access to the needed services, communicating to them effectively and understanding them. The presence of professions in universities as students with unique needs today who come to either update their knowledge or further their education has presented an inimitable challenge to these universities (Navarro, Iglesias, \& Torres, 2005). In their study to identify what determines student satisfaction, Navarro, Iglesias and Torres (2005) found that the students especially in this category measure the service quality they receive from these universities based on the reliability and responsiveness of the service providers. These two factors together with the management of the institution directly influenced the students' satisfaction level on the service quality they receive from the educational institutions. In addition, Gruber, Fub, Voss and Glaser-Zikuda (2010) argue the employee who has a direct interaction with customers the way they behave and their attitudes to the customers largely impacts on the perceptions customers form regarding the service quality offered by the organizations. Thus the human element in the customer interaction is important in determining whether student will be satisfied with the university services or not. A study by Sultan and Wong (2010) revealed that where human elements of dependability, effectiveness, capability, efficiency, competencies and assurance were among the influencing factors of student satisfaction in Japanese universities support this fact. In addition, Zeithaml et al. (2006) explained the concept of service quality as the assessment of the customers' perception of the five dimensions of quality in SERVQUAL model. In this study however reliability was singled out as offering the most influence over the other dour dimensions. The study by Owino (2013) and that of Smith, Smith and Clarke (2007) empirically support this argument as both studies found reliability to be the most influencing dimension in order of magnitude. The increased competitions in the market and the dynamics of customer service needs and demands have made service organizations to improve efficiency in their service processes (Mascio, 2007). According to Tamrakar (2010) Service delivery may be viewed from both the point of view of one providing and the one receiving the services. For an effective service delivery, the service seekers must have a pervasive awareness of the services they are supposed to receive. The service provider on their part must be knowledgeable on the services they are supposed to offer and how they are supposed to offer them. In other words, both the employees in the organizations and the customers must know what to expect in the service delivery process, lack of which would create a serious service gap. In building a service culture environment for an organization, the management must bring on board the right employee, develop and upgrade their skills, motivate and retain them in order for them to deliver the needed quality service. For example, a study to establish how service charter influences service delivery at Nairobi City Water and Sewerage Company found that, the organization needed to invest in Staff consultations and Staff training access to copies (Mwania, 2015). Thus all employees in a Public University must treat students with courtesy and show empathy to their concerns. That is, approaching them using accepted and appropriate manners, as viewed from the students' perspective in order to meet their expectations (Steve, 2013).

\section{Objective of the study}

To evaluate the influence of human elements on student satisfaction in Public universities in Kenya 


\section{Hypothesis of the Study}

$\mathrm{H}_{01}$ : Human elements have no statistical significant relationship with student satisfaction in public universities in Kenya

\section{Methodology}

The study was carried out in five selected public universities in Kenya which had a total population of 270,120 students. A sample of 1976 students was picked from the five p[ublic universities as follows; University of Nairobi, 398 students, Kenyatta University, 398 students, Jomo Kenyatta University of Agriculture and Technology, 396 students, Moi University 396 students and Egerton University 388 students. Descriptive research design was employed in this study. Descriptive research has been explained as the characteristics of a target group and is more suitable in estimating the percentage of units in a target population, display certain behaviour, influencing the perception of product characteristics, degree of association between various marketing variables and making specific predictions (Jackson, 2009). In a study to establish how customer satisfaction is influenced by corporate image and service quality, Owino (2013) viewed descriptive design as one that enables the researcher to generalize the findings of a sample survey to the population. Descriptive survey was adopted as the most appropriate for achieving the research objective as per the research problem and philosophy of this study. Primary data was collected with a purpose of addressing the research problem and the objectives. A structured questionnaire which consisted of 5 point likert scales constructed to collect the data. A 5 point scales reduce the level of frustration among respondents, and increases the rate and quality of the responses (Prayag, 2007). According to Newing (2011) and Bryman (2008), a questionnaire consists of a series of specific, usual short and precise questions that are asked verbally through an interview, or answered by respondents by themselves. In this study, variable measuring items were indicated as simple statements where the respondent selected their answers based on the five options in a 5point Likert-type scale. The five-point Likert scale measured the items where 5= Strongly Agree, $4=$ Agree, $3=$ Neutral, 2 Disagree 1=, Strongly Disagree. A pilot study was carried out before the full scale survey to examine the validity and reliability of the data collection instrument. To ascertain the consistency of the measurement sets as suggested by Fornell and Larcker, (1981), reliability test was carried out on the data Cronbach's alpha, a coefficient of reliability given by Cronbach (1971), which provides an unprejudiced estimate of data generalization alpha was used (Zinbarg, Revelle, Yovel, \& Li, 2005 ). Cronbach's alpha assessment explains how highly the questionnaire's items are interrelated (Pallant, 2007). Cronbach alpha coefficients were calculated to measure the reliability / internal consistency of the instrument. The acceptable reliability co-efficient had been recommended as 0.7 and above Nunnally (1978). For this study the Cronbach alpha coefficients were 0.944 and 0.801 for human elements and student satisfaction respectively. The study adopted a pick drop and method of administering the questionnaires where the students in the respective public universities were issued the questionnaires and later allowed to dropped them at a designated point in their institution. Multiple regression analysis was used to pinpoint the service quality dimensions (independent variables) that influence student satisfaction (dependent variable). Multiple regression was also used to identify the effect of service charter in the influence of service quality on student satisfaction. The process of testing the hypotheses started by testing first the direct effect of independent variables on the dependent variable whose relationship must be significant for the moderations effect to be tested (Aiken \& West, 1991). The hierarchical regression analysis was undertaken to assess relationship between predictors and the dependent variables. The study first assumed a linear relationship between the service quality dimensions (predictor variables) and student satisfaction (dependent variables) after establishing the assumptions of Ordinary Least Squares (OLS). A regression model to explain the possible relationship was given by the following equation (Aiken \& West, 1991; Fairchild \& MacKinnon, 2010). From the perceived relationship between the independent variables and the dependent variable, the following linear functional Tangible element and student satisfaction: $\mathrm{H}_{02}: \mathrm{SSN}=\beta_{0}+\beta_{2}$ TE, $+\mathrm{e}($ Where; $\mathrm{SSN}=$ Student Satisfaction, $\beta 0=$ Constant, TE $=$ Tangible Elements and $\mathrm{e}=$ error term). In the second part of the analysis the moderator, service charter was added in a multiple regression analysis where the following regression equation was estimated; $\mathrm{Y}=\beta_{0}+\beta_{1} X_{1}+\beta_{2} X_{2}+$ $\varepsilon$ (Where; $\beta_{0}=$ was the estimate of the intercept, $\beta_{1}=$ Coefficient of the independent variable, $\beta_{2}=$ Coefficient of moderating variable, $X_{1}=$ independent variable, $X_{2}=$ University Service charter while $\varepsilon=$ was the associated regression error term while $\mathrm{Y}=$ was the dependent variable (student satisfaction). The analyses of $\mathrm{R}^{2}$ to establish the change in $\mathrm{R}^{2}$ in the moderated effect model was then undertaken in accordance to the formular suggested by Aiken and West (1991). The study rejected the null hypothesis if the the change in $\mathrm{R}^{2}$ after adding the moderating variabe was significantly more than $\mathrm{R}^{2}$ before the moderator was added in the model (Aiken \& West, 1991).

\section{Results and Discussion}

The human element dimension composed of four components Human elements, reliability, responsiveness, assurance and empathy. The study carried out the hierarchical multiple regressions to assess how human elements related with student satisfaction. Hierarchical regression was chosen simply because it could allow the assessment of individual variable and a combination of independent variables. The findings of the study on the human 
elements variables as shown in Appendix V showed that all the variables presented an overall significance of their regression model with $\mathrm{p}$-values less than 0.05 at $\alpha=0.05$ (Reliability $\mathrm{F}=1255.66 \mathrm{p}<0.05$, Responsiveness $\mathrm{F}=1359.490, \mathrm{p}<0.05$, Assurance $\mathrm{F}=1507.174, \mathrm{p}<0.05$ and Empathy $\mathrm{F}=1917.589, \mathrm{p}<0.05)$. The model summary for these variables also revealed that each of the variables coefficients of determination $\left(\mathrm{R}^{2}\right)$ explained the variation of the dependent variable (student satisfaction) with varying levels (Reliability $44.3 \%$, Responsiveness $46.3 \%$, Assurance 48.8\% and Empathy 54.8\%). This implies that, among the individual variables of human elements, empathy is the most critical factor which contributes most to students' satisfaction. These results were similar to the finding of Hasan and Ilias (2008) who in their study to establish how student satisfaction related with service quality at a private higher education institutions found empathy to be strongly related to satisfaction followed by assurance, responsiveness and reliability. However, Zeithaml et al. (2006) had a conflicting observation that reliability is the most important dimension in service quality although service regardless of whether quality is a focused evaluation that reflects the customers' perception of all the five mentioned service quality dimensions (reliability, tangibility, responsiveness, assurance and empathy). Other studies such as Perisau and McDaniel (1996) found assurance as the most critical variable in the human elements and not empathy. Hierarchical multiple regression was employed to evaluate the ability of the combined human elements to predict levels of student satisfaction. The study findings of the model summary for the combined variables of human elements and student satisfaction in Table 4.20 revealed that the coefficient of determination $\left(\mathrm{R}^{2}\right)$ was 0.620 , which implies that human elements (reliability, responsiveness, assurance and empathy), explained 62 percent of the variations in student satisfaction.

Table 4. 1: Model Summary of Human Elements and Student Satisfaction

\begin{tabular}{cccccc}
\hline Model & R & R Squared & Adjusted R Square & $\begin{array}{c}\text { Std. Error of the } \\
\text { Estimate }\end{array}$ & Durbin-Watson \\
\hline $.787 \mathrm{a}$ & .620 & .601 & .521 & 1.915 \\
\hline
\end{tabular}

a. Predictors: (Constant), Human Element

b. Dependent Variable: Students Satisfaction

It is however interesting to note above findings that, the combined human element variable $\left(\mathrm{R}^{2} 0.620\right)$ explained the variation of students' satisfaction more than any of its single variable of reliability, responsiveness, assurance and empathy. This implies that all the variables in the human elements are important and should be observed when offering services to students at public universities. In addition, the study used ANOVA examine the overall significance of the regression model. In the analysis of variance statistics of human elements in Table 4.21, the F-value was 2575.326 and the p-value was 0.000 . These results shows that the model was significant with p-values less than 0.05 at $\alpha=0.05$ level in explaining the human elements and student satisfaction linear relationship.

Table 4. 2: Analysis of Variance (ANOVA) Statistics of Human Elements

\begin{tabular}{lccccc}
\hline Model & Sum of Squares & df & Mean Square & F & Sig. \\
\hline Regression & 697.907 & 1 & 697.907 & 2575.326 & $.000^{\mathrm{b}}$ \\
Residual & 427.905 & 1579 & .271 & & \\
Total & 1125.812 & 1580 & & & \\
\hline
\end{tabular}

a. Dependent Variable: Students Satisfaction

b. Predictors: (Constant), Human Element

Finally, the study examined the significance of the human element variable and as shown by the coefficient in Table 4.22, Human elements had t-value of 50.748 and a p-value of 0.000 which was significant. Thus the study concluded that the relationship between human elements and student satisfaction was significant. These results concurred with other studies of were similar with those of other studies of Ilias, Rahman and Razak (2008) who found the service quality dimensions of assurance, responsiveness, reliability and empathy to have significant relationship with student satisfaction. Similarly, Owino (2013) in the study to find out the relationship between customer satisfaction and corporate image and service quality in the Kenyan private and public universities also found human elements to have significant relationship with student satisfaction (F-value $(1,742)$ was 722.996 and the p-value was 0.000$)$. Using the coefficients results in Table 4.22, the relationship between human elements and student satisfaction was presented by the fitted model as:

Table 4. 3: Coefficients of Human Elements

\begin{tabular}{|c|c|c|c|c|c|}
\hline \multirow{2}{*}{ Model } & \multicolumn{2}{|c|}{ Unstandardized Coefficients } & \multirow{2}{*}{$\begin{array}{c}\text { Standardized Coefficients } \\
\text { Beta }\end{array}$} & & \multirow{2}{*}{ Sig. } \\
\hline & $\mathrm{B}$ & Std. Error & & & \\
\hline (Constant) & .235 & .049 & & 4.752 & .000 \\
\hline Human Element & .929 & .018 & .787 & 50.748 & .000 \\
\hline
\end{tabular}

$\mathrm{SS}=.235+.929 \mathrm{HE}+\varepsilon, \quad \mathrm{R}^{2}=0.620$ 


\section{Conclusions}

The positive statistically significant relationship between human elements and student satisfaction implies that the management of public universities in Kenya can maximize on the qualities of their employee in order to enhance student satisfaction. This means that the university management need to invest in staff continuous training, provide the necessary motivation in order for them to understand and deliver quality service to students. Human elements components of reliability, responsiveness, assurance and empathy were all found to be positively related to student satisfaction. Thus the higher the level of adherence to service quality dimensions by university staff who offers services to students the higher the student satisfaction levels will be in Kenyan public universities.

\section{Recommendations}

This study recommends that management of public universities develop and maintain a student oriented and service minded staff who can effectively and reliably deliver quality service to students. In this regards, the management must continuously invest in staff development and motivation to ensure high standard of service delivery that leads to student satisfaction.

\section{References}

Abagi , O., Nzomo, J., \& Otieno, W. (2010). Private Higher Education in Kenya. International Institute of Education Planning. Paris: UNESCO.

Abagi, O. J. (1999). Resource Utilization in Public Universities in Kenya. Enhancing Efficiency and Cost Recovery Measures. Nairobi: IPAR.

Abomaleh, A. A., \& Zahari, I. Z. (2014). Abomaleh The impact of management commitment to service quality and customer satisfaction:. A Review of Saudi Arabia public service sector, 3(2).

Anderson, E., \& Fornell, C. (1994). “A Customer Satisfaction Research Prospectus.”. In R. R. (eds.), Service Quality : New Directions in Theory and Practice (pp. 241-268.).

Bohlander, G. W., \& Kinicki, A. J. (1988). Where personnel and productivity meet. The Personnel Administration, 33(9), 122-130.

Bombard, P. M. (1990). Commitment to the Customer. Bests' Review, 91(6), 141-144.

Bowen, D. E., \& Lawler, E. E. (1992). The Service Encounter: Diagnosing Favorable and Unfavorable Incidents. Journal of Marketing, 54, 31-39.

Chen, Pei-Yu , \& Hitt, L. (2002). "Measuring Switching Costs and their Determinants in Internet Enabled Businesses: A Study of the Online Brokerage Industry”. Information Systems Research, 13(3), 255-276.

Cronbach, L. J. (1971). Education Measurement. (2nd ed.). Washington DC: American council of Education.

CUE. (2017, June 17). Status of Universities. Retrieved from Commission forr University Education: http://www.cue.or.ke

GoK. (1988). Report of the Presidential Working Party on Education and Manpower Training for the Next Decade and Beyond. Nairobi.: Government Printer.

Gruber, T., Fub, S., Voss, R., \& Gläser-Zikuda, M. (2010). Examining Student Satisfaction ith Higher Education Services: Using a New Measurement Tool. International Journal of Public Sector Management, 23(2), 105 $-123$.

Hasan, H. F., \& Ilias, A. (2008). Service Quality and Student Satisfaction: A Case Study at Private Higher Education Institutions. International Business Research, 1(3), 165- 173.

Ilias, A., Hasan, H., Rahman, R. A., \& Yasoa, ,. M. (2008). "Student Satisfaction and Service Quality: Any Differences in Demographic Factors?,". International Business Research, 1(4), 31-143.

Jenkins, K. J. (1992). Service Quality in the Skies. Business Quarterly, 57(13), 13.

Kiboiy, K. L. (2013). The Dynamics of Student Unrests in Kenya's Higher Education: The case of Moi University. . $\mathrm{PhD}$ Thesis, University of Pretoria, Pretoria.

Mark, E. (2013). Student Satisfaction and the Customer Focus in Higher Education. Journal of Higher Education Policy and Management, 35(1), 2-10.

Navarro, M. M., Iglesias, M. P., \& Torres, M. P. (2005). Measuring Customer Satisfaction in Summer Courses. Quality Assurance in Education, 13(1), 53-65.

Newing, H. (2011). Conducting Research in Conservation: A Social Science Methods and Practice. London: Taylor and Francis Publishers.

Ngware, M. S., Onsomu, E. N., \& Manda, D. K. (2005). Private Sector Investment in Education and Training: A Case of Tertiary Education in Kenya, Special Report No.7. Nairobi: Kenya Institute for Public Policy Research and Analysis.

Nunnally, J. C. (1978). Psychometric Theory, 2nd Ed. New York, NY: Mcgraw-Hill Book Company.

Otieno, W., \& Levy, D. (2007). Public Disorder, Private Boons? . Inter-Sectorial Dynamics.

Owino, E. O. (2013). The influence of service quality and corporate image on customer satisfaction among university students in Kenya, , . Uniersity of Nairobi, School of Business. Uniersity of Nairobi. 
Prayag, G. (2007). “Assessing International Tourists' Perceptions of Service Quality at Air Mauritius". International Journal of Quality \& Reliability Management, 24(5).

Rust, R. T., \& Oliver, R. L. (1994). Service Quality: Insights and Managerial Implications from the Frontier. In R. T. Rust \& R. L. Oliver (Eds.), Service Quality: New Directions in Theory and Practice (pp. 1-19). Thousand Oaks: Sage Publications.

Sifuna, N. D. (1998). The Governance of Kenyan Public Universities. In Research in Post-Secondary Education. Volume 3 NO.2 Social Development Working Paper No.2. London: DFID.

Smith, G., Smith, A., \& Clarke, A. (2007). Evaluating Service Quality in Universities: A Service Department Perspective. Quality Assurance in Education, 15(3), 334 - 351.

Steve , C. (2013). Delight Your Customers: 7 Simple Ways to Raise Your Customer Service from ordinary.

Sultan, P., \& Wong, H. (2010). Performance Based Service Quality Model: An Empirical Study of Japanese Universities. Quality Assurance in Education, 18(2), 126-143.

Tamrakar, R. (2010). Impact of Citizen Charter in Service Delivery: A Case of District Administration Office,. Kathmandu.

Tierney, W. G. (1998). The Responsive University; Structuring for High Performance. London: Blatmore.

Y1lmaz, İ. (2009). Measurement of Service Quality in the Hotel Industry. An International Journal of Tourism and Hospitality Research, 20(2), 375-386.

Zeithaml, V. A., Bitner, M. J., \& Gremler, D. D. (2006). Service Marketing: Integrating Customer Focus Across the Firm (4th Ed.). New York: McGraw-Hill International. 